\title{
Design and Construction of Low Cost Water Harvesting Gabion Structure - An Alternative to Expensive Check Dams
}

\author{
Purnima Mishra $^{1^{*}}$ and R.R. Babu ${ }^{2}$ \\ ${ }^{1}$ Department of Horticulture Engineering, College of Horticulture, SKLTSHU, \\ Rajendranagar, Hyderabad - 500030, India \\ ${ }^{2}$ NABARD, Bandra Kurla Complex, Bandra (East), Mumbai - 400051, India
}

*Corresponding author

\begin{tabular}{|l|}
\hline Ke y w o r d s \\
Gabion structure, \\
$\begin{array}{l}\text { Water harvesting, } \\
\text { Low cost, Check } \\
\text { dam }\end{array}$ \\
\hline Article Info \\
\hline $\begin{array}{l}\text { Accepted: } \\
\text { 14 November } 2020 \\
\text { Available Online: } \\
\text { 10 December } 2020\end{array}$ \\
\hline
\end{tabular}

A B S T R A C T

\section{Introduction}

Construction of gully control structures across the drainage line is an important activity in any watershed development programme. However, design of these structures requires quantification of peak runoff rate for the design return period (Ravi Babu et al., 2006). Further, construction of series of gully plugs and masonry structures at appropriate locations in the drainage line of any watershed help in reducing the channel gradient and stabilizing the grade of gully. Proper design and construction is vital for long life and dependability of permanent soil and water conservation engineering structures (Mishra and Ravi Babu, 2008). These gully control structures including gabion and masonry check dams reduce the velocity of flowing water and allows the water to infiltrate and recharge the aquifers Dashora, et al., (2018) used simple methods and 
concluded the beneficial impact of check dams in ephermal streams on the aquifer recharge in Rajasthan state of India. In the present study the design of regular Gabion Structure has been modified to facilitate storage of rainwater in addition to reducing flow velocity and controlling soil erosion in the middle reaches of the drainage line in watersheds as a low cost alternative to expensive masonry check dams.

Gabion structures are made with boulders packed in wire mesh cages made with Galvanized Iron (GI) wire of about 10 gauge thickness with mesh size of 7.5-10 cm. They are constructed in main gullies for retention of soil and other debris without ponding. These structures also encourage good vegetative growth along the banks and bed of the stream due to increased moisture regime. Gabion structures have a longer life than loose boulder gully plugs. Generally, Gabions are $1 \mathrm{~m}$ to $1.5 \mathrm{~m}$ wide with height up to $1 \mathrm{~m}$, while their length can vary between 2 to $10 \mathrm{~m}$ depending on gully width. These are preferred in middle reaches of watersheds (Ravi Babu, 2009).

The design of regular Gabion Structure has been modified to facilitate storage of rainwater in addition to reducing flow velocity and controlling soil erosion in the middle reaches of the drainage line in watersheds. This design was successfully field tested in Laxmipur watershed falling in Karimnagar district of Telangana state. The design and cost details and specific modifications made in design and construction of water harvesting gabion structure etc., are presented in this paper.

\section{Materials and Methods}

First the longitudinal profile of the gully was studied. The structure is identified for construction at the narrow section of the gully as minimum earth and stone work is involved in Laxmipur watershed in Karimnagar district of Telangana state. The identified site for Gabion structure has straight approach channel above it. The depth of hard strata from the surface was checked by trial pitting to finalize the depth of foundation to be made. The site conditions particularly width and depth of gully were also studied.

The catchment of proposed structure, prevailing land use/cover, slope and soil texture in the catchment were studied. Considering the prevailing land use, land slope and soil texture, etc., the runoff coefficients were assigned from the table given in Dhruvanarayana, (2002) and the weighted runoff coefficient for the catchment was worked out. Further, the intensity of rainfall for 15 year return period and for the duration equal to time of concentration was evaluated. The rational formula was used for estimating the design peak runoff rate from the catchment of the structure. The dimensions of structure (i.e. hydraulic design) were finalized to handle runoff from 40 ha catchment. Further, the conventional design and construction of Gabion structure has been modified to facilitate storage of rainwater in addition to reducing flow velocity and controlling soil erosion. The modifications in the design and construction of gabion structure included the following:

After making the foundation for the entire base width of head wall the gabion wire of 8 gauge was spread taking into account total perimeter of head wall. The foundation of vertical portion of head wall was made with concrete (1:6:10). The width of vertical portion of head wall was kept equal to top width of head wall. The vertical portion of head wall above the foundation was made with the stone and cement mixture. Later the upstream and downstream sloping portions of head wall were filled with stones from the foundation. Wearing coat with cement of 5 $\mathrm{cm}$ thickness is made on the vertical portion 
of the head wall. Sunken pit $(8 \times 8 \times 1 \mathrm{~m})$ on the upstream side of structure (at a distance of $2 \mathrm{~m}$ from the structure) was added to increase the storage capacity and to reduce the pressure of flowing water on the structure.

\section{Results and Discussion}

The width and depth of gully at the site of construction were 10 and $1.5 \mathrm{~m}$, respectively. The catchment of the structure was 40 ha, of which 10 ha was under forest cover and 30 ha was under agriculture. The texture of the soil was sandy loam. The design peak rate of runoff was found to be 4.2 cumec. The length of weir of $10 \mathrm{~m}$ and depth of flow over the weir (including free board) was considered as $0.45 \mathrm{~m}$ to safely dispose the estimated peak flow rate of runoff. The height of structure was kept at $0.75 \mathrm{~m}$. The details of design dimensions of different components of the structure, volume of work (earth, cement concrete, stone and mortar, etc.), gabion wire requirement and cost involved, etc., are presented in Table 1.

As the depth of hard strata was found to be at $0.3 \mathrm{~m}$, foundation up to a depth of $0.3 \mathrm{~m}$ was made for head wall/body wall including core walls (head wall extension), apron and side walls. To ensure stability of structure, the head wall extension i.e. core wall is keyed into the stable portion on both sides of gully by $0.6 \mathrm{~m}$. Trapezoidal cross section with top width of $0.6 \mathrm{~m}$ and height of $0.75 \mathrm{~m}$ was considered for head wall. The weir depth (from top of core wall to top of head wall) of $0.45 \mathrm{~m}$ (including free board) was maintained for free over fall of excess water. On the upstream side Gabion structure, side slope of 1: 1 and on the downstream side flatter slope of 1.5: 1 was maintained. The length of apron was set equal to the length of head wall and the width of apron was kept as $2 \mathrm{~m}$.

After making the foundation, the gabion wire of 8 gauge was spread taking into account total perimeter of head wall. The foundation of vertical portion of head wall was made with concrete $(1: 6: 10)$. The vertical portion of head wall above the foundation was made with the stone and cement mixture. The base width of vertical portion of head wall was kept equal to top width of head wall. Later the upstream and downstream sloping portions of head wall were filled with stones from the foundation. When the stone packing was complete the sides and flaps are pulled tightly over the stones and tied up with extra wire extending from the mesh or by using separate wire pieces. Wearing coat with cement of 5 $\mathrm{cm}$ thickness was made on the vertical portion of the head wall. Apron of $2 \mathrm{~m}$ width with dry stone packing was made. Toe wall with crosssection of $0.45 \times 0.45 \mathrm{~m}$ was made with dry stone packing to support the structure from piping and drifting.

A Sunken pit $(8 \times 8 \times 1 \mathrm{~m})$ on the upstream side of structure (at a distance of $2 \mathrm{~m}$ from the structure) was made to increase the storage capacity and to reduce the pressure of flowing water on the structure. The cost of the structure including the sunken pit was Rs. 55,000/- against the estimated cost of Rs. 2 lakh for constructing the pacca check dam at the same site. The constructed water harvesting Gabion structure was able to harvest 10 lakh litres of rain water (with two fillings) in a year. As the gabion wire mesh is in touch with water, the problem of rusting of wire mesh was noticed. After carefully observing the performance of the structure the following changes are suggested for its long term durability:

To avoid rusting of gabion wire wearing coat of $5 \mathrm{~cm}$ thickness with cement is to be made on sloping portions of head wall.

Cutoff wall with cement concrete of $0.6 \mathrm{~m}$ depth may be added on the up stream and downstream sides of head wall to avoid failure of structure due to overturning (Fig. 1). 
Table.1 Detailed estimate for the water harvesting gabion structure

\begin{tabular}{|c|c|c|c|c|c|c|c|c|}
\hline S. No & Description of Item & No. & Length & Breadth & Depth & Quantity & $\begin{array}{c}\text { Rate/ } \\
\text { per cubic } \mathrm{m}\end{array}$ & $\begin{array}{c}\text { Amount - } \\
\text { rounded (Rs.) }\end{array}$ \\
\hline 1 & 2 & 3 & 4 & 5 & 6 & 7 & 8 & 9 \\
\hline 1 & \multicolumn{8}{|c|}{ Earth work excavation for foundation with an initial lead of $10 \mathrm{~m}$ and lift of $2 \mathrm{~m}$} \\
\hline & Body wall & 1 & 10 & 2.5 & 0.3 & 7.5 & & \\
\hline & Apron & 1 & 10 & 2 & 0.3 & 6 & & \\
\hline & Core walls & 2 & 0.6 & 0.6 & 1.5 & 1.08 & & \\
\hline & Toe wall(D/s) & 1 & 10 & 0.45 & 0.45 & 2.03 & & \\
\hline & Foundation for side slopes & & & & & & & \\
\hline & Upstream (1.0:1.0) & 1 & 10 & 0.75 & 0.3 & 2.25 & & \\
\hline & Downstream (1.5:1) & 1 & 10 & 1.13 & 0.3 & 3.38 & & \\
\hline & Side walls & 2 & 3.9 & 0.3 & 1.5 & 3.51 & & \\
\hline & & & & & & 25.75 & 64 & 1648 \\
\hline \multirow[t]{4}{*}{2} & Laying of C.C.(1:6:10) mix in foun & on wi & h $40 \mathrm{~mm}$ & metal & & & & \\
\hline & Body wall & 1 & 10 & 0.6 & 0.3 & 1.8 & & \\
\hline & Core walls & 2 & 0.6 & 0.6 & 0.3 & 0.216 & & \\
\hline & & & & & & 2.016 & 2011 & 4054 \\
\hline \multirow[t]{4}{*}{3} & Construction of R.R. Masonry in & $(1: 6)$ & & & & & & \\
\hline & Body wall Above GL & 1 & 10 & 0.6 & 0.75 & 4.5 & & \\
\hline & Core walls & 2 & 0.6 & 0.6 & 1.2 & 0.864 & & \\
\hline & & & & & & 5.364 & 1866 & 10009 \\
\hline \multirow[t]{10}{*}{4} & 0.225M Rough Stone dry packing & lete. & & & & & & \\
\hline & Body wall Below GL & 1 & 10 & 2.5 & 0.3 & 7.5 & & \\
\hline & Above GL U/S(1:1) & 0.5 & 10 & 0.75 & 0.75 & 2.8125 & & \\
\hline & $\mathrm{D} / \mathrm{S}(1.5: 1)$ & 0.5 & 10 & 1.13 & 0.75 & 4.2375 & & \\
\hline & Apron & 1 & 10 & 2 & 0.3 & 6 & & \\
\hline & Toe wall(D/s) & 1 & 10 & 0.45 & 0.45 & 2.03 & & \\
\hline & Side walls & 2 & 3.9 & 1.5 & 0.3 & 3.51 & & \\
\hline & Sub-Total & & & & & 26.09 & & \\
\hline & Deduct wall portion & 1 & 10 & 0.6 & 0.3 & 1.8 & & \\
\hline & & & & & & 27.89 & 540 & 15061 \\
\hline \multirow[t]{3}{*}{5} & $\begin{array}{l}\text { Chain link mesh } 8 \text { gauge } 5 \times 5 \mathrm{~cm} \\
(50.80 \mathrm{~mm} \times 50.80 \mathrm{~mm})\end{array}$ & & & & & & & \\
\hline & & 1 & 10 & 7.9 & & 79 & 265 & 20935 \\
\hline & Sub-Total & & & & & & & 51707 \\
\hline \multirow[t]{3}{*}{6} & Sunken pit $(8 \times$ x 8 x 1 m) & 1 & 8 & 8 & 1 & 64 & 47 & 3008 \\
\hline & Total & & & & & & & 54715 \\
\hline & Total rounded to & & & & & & Say & 55000 \\
\hline
\end{tabular}


Fig.1 Cross-section of water harvesting gabion structure

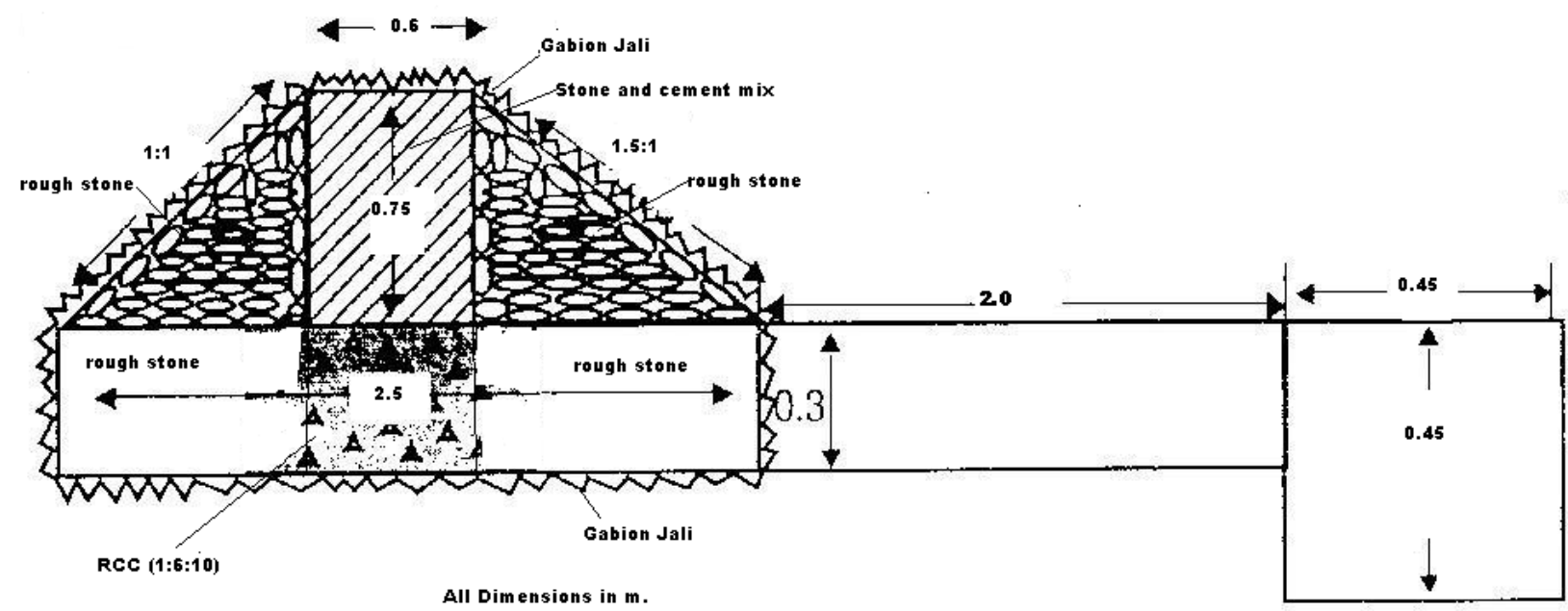

In conclusion, the modified low cost water harvesting gabion structure is expected to serve as a low cost alternative to expensive masonry check dams. This structure could be made in place of expensive check dams in the middle reaches of watersheds with catchments up to 50 ha for harvesting precious rain water in addition to reducing flow velocity and controlling soil erosion.

\section{References}

Dashora Y, Dillon P, Maheshwari B, Soni P, Dashora R, Davande S, Purohit RC, Mittal HK (2018) A simple method using farmers' measurements applied to estimate check dam recharge in Rajasthan, India. Sustain. Water Resource. Manag. 4: 301-316. https://doi.org/10.1007/s40899-017-
0185-5

Dhruvanarayana, V.V. 2002. Soil and water conservation research in India. ICAR publication, New Delhi.

Mishra, P. and Ravi Babu, R. 2008. Application of advanced Hydrology tools of GIS for field level design of a drop structure. Journal of Soil and Water Conservation, 7(2): 16-24.

Ravi Babu, R. 2009. Field manual on design and cost estimation of soil and water conservation measures for watershed development projects. $54 \mathrm{p}$.

Ravi Babu, R., Mishra, P. Mazumdar, A. and Roy, D. 2006. Probability Analysis of Rainfall of Bankura for Design of Soil and Water Conservation Structures. Journal of Agricultural Engineering. 43(1): 22-29.

\section{How to cite this article:}

Purnima Mishra and Babu, R.R. 2020. Design and Construction of Low Cost Water Harvesting Gabion Structure - An Alternative to Expensive Check Dams. Int.J.Curr.Microbiol.App.Sci. 9(12): 1771-1775. doi: https://doi.org/10.20546/ijcmas.2020.912.209 